\title{
ARTICLE
}

\author{
Susan Saab Fortney
}

\section{The Role of Ethics Audits in Improving Management Systems and Practices: An Empirical Examination of Management-Based Regulation of Law Firms}

\begin{abstract}
For decades, legal malpractice experts have urged lawyers to implement risk management measures. To assist law firms in doing so, legal malpractice insurers have provided audit services and self-audit materials. Under the Australian regulatory regime, incorporated legal practices are required to complete a self-assessment process and to report on the firm's compliance with ten objectives of sound law practice. Using management-based principles, this Article discusses steps to take to encourage ethics audits "to merge good ethics and good business" in the U.S.

Author. Susan Saab Fortney serves as the Howard Lichtenstein Distinguished Professor of Legal Ethics and Director of the Institute for the Study of Legal Ethics at Maurice Deane School of Law at Hofstra University. Professor Fortney has conducted various empirical studies on law firm ethics and liability. She works with numerous bodies including The Professional Lawyer, the State Bar of Texas Committee on the Disciplinary Rules of Professional Conduct, and the National Conference of Bar Examiners Committee that drafts the Multistate Professional Responsibility Examination. Texas Lawyer newspaper selected her as one of the Thirty Extraordinary Women in Texas Law. In 2010, the Texas Bar Foundation awarded her the Lola Wright Foundation Award for outstanding public service in advancing legal ethics. She is a member of the American Law Institute, the Texas Bar Foundation, and the American Bar Foundation.
\end{abstract}




\section{ARTICLE CONTENTS}

Introduction. ........................ 114

Part I - Research Questions and Methodology . . . . 120

Part II - Select Survey Findings .............. 121

Part III - Integrating Management-Based Principles. 125

A. Regulatory Mandate Related to Alternative

Business Structures . . . . . . . . . . . . . . . 126

B. Use of Management-Based Approaches As an

Alternative to Discipline................. 127

C. Insurers' Role in Promoting Self-Assessment and Development of Systems . . . . . . . . . . 138

D. The Role of Privileges ................. 141

Conclusion: Building Partnerships Among

Practitioners, Regulators and Insurers . . . . . . . . . 147 


\section{INTRODUCTION}

On a weekly basis, articles in both legal newspapers and the popular press question the relevance, cost, and application of legal education. ${ }^{1}$ This discussion adds another chapter to discourse on the role of law school and legal educators. In the debate on the proper focus of law schools and legal educators, Judge Harry Edwards of the United States Court of Appeals for the D.C. Circuit challenged law schools and law firms to examine the "disjunction" between the legal academy and the legal profession. $^{2}$ Judge Edwards questioned the emphasis on abstract theory, arguing that the principal mission of law schools should be to produce "scholarship that judges, legislators, and practitioners can use."3 According to Judge Edwards, "'practical' scholarship ... is not wholly doctrinal." ${ }^{4}$ Rather he noted that a "'practical scholar' gives due weight to cases, statutes, and other authoritative texts, but also employs theory to criticize doctrine, to resolve problems that doctrine leaves open, and to propose changes in the law or in systems of justice." 5

At the time that Judge Edwards referred to the "disjunction," Judge Edwards may not have been aware of Ted Schneyer's seminal article,

1. See Tania Karas, Law Schools Bolster CliniC Offerings, N.Y. L.J. 5 (2013) (describing how New York law schools are using clinics to help students develop practical lawyering skills and prepare them for jobs); see also Deborah L. Rhode, Legal Education: Rethinking the Problem, Reimaging the Reforms, 40 PEPP. L. REV. 437, 438 (2013) (providing a scholarly analysis of the concerns related to the future of legal education); Ethan Bronner, A Call for Drastic Changes in Educating New Lawyers, N.Y. TIMES (Feb. 10, 2013), http://www.nytimes.com/ 2013/02/11/us/lawyers-call-for-drastic-change-in-educating-new-lawyers.html?_r=0 (referring to testimony presented at hearings conducted by the American Bar Association's Task Force of the Future of Legal Education); Randall T. Shepard, Task Force on the Future of Legal Education, A.B.A. CENTER FOR PROF. RESP., http://www.americanbar.org/groups/professional_responsibility/ taskforceonthefuturelegaleducation.html (last visited Mar. 19, 2014) (indicating that the ABA Task Force on the Future of Legal Education is "charged with making recommendations to the $[A B A]$ on how law schools, the $\mathrm{ABA}$, and other groups and organizations can take concrete steps to address issues concerning the economics of legal education and its delivery").

2. See Harry T. Edwards, The Growing Disjunction Between Legal Education and the Legal Profession, 91 MICH. L. REV. 34, 34 (1992) (expressing his concern that the legal education system and the legal profession are growing in opposite directions). Subsequently, the Michigan Law Review published a symposium issue focusing on the subject of the growing disjunction. See generally Richard A. Posner, The Deprofessionalization of Legal Teaching and Scholarship, 91 MICH. L. REV. 1921 (1993) (responding to Judge Harry Edwards's article).

3. Harry T. Edwards, The Growing Disjunction Between Legal Education and the Legal Profession, 91 MiCH. L. REV. 34, 34 (1992).

4. Id. at 35 .

5. See id. (noting that a good legal scholarship is not one dimensional); see also Richard A. Danner, Oh, The Treatise!, 111 MICH. L. REV. 821, 822 (2013) (pointing out that in recent years, Chief Justice Roberts and Justice Kennedy have also questioned the value of purely theoretical legal scholarship). 
Professional Discipline in Law Firms. ${ }^{6}$ The article critically examined problems facing practitioners and proposed changes to improve the effectiveness of regulation of lawyers. ${ }^{7}$ Arguing that the professional regulation should include the discipline of law firms, Professor Schneyer analyzed how limiting discipline to individual lawyers does not address various ethical breaches that arise from inadequate organizational controls and deficiencies in the ethical infrastructure of law firms. ${ }^{8}$ Professor Schneyer first used the term "ethical infrastructure" to refer to "a law firm's organization, policies, and operating procedures ... that cut[] across particular lawyers and tasks." " Professor Schneyer suggested that "[t]he chief reason to allow disciplinary authorities to proceed directly against law firms is prophylaxis - the promotion of firm practices that prevent wrongdoing by individual lawyers." ${ }^{10}$ As discussed below, Professor Schneyer's work on the discipline and ethical infrastructure of law firms has influenced lawyers, academics, jurists, and regulators around the world. ${ }^{11}$

Following the publication of Professor Schneyer's article, the high court in New York revised the state's professional conduct rules to provide for discipline of law firms as entities. ${ }^{12}$ Although few firms have been disciplined, the possibility of entity discipline should motivate firm leaders to devote time and resources to implement policies and procedures to promote ethical conduct. ${ }^{13}$

In focusing attention on the connection between ethical conduct and

6. Harry T. Edwards, The Growing Disjunction Between Legal Education and the Legal Profession, 91 MiCH. L. REV. 34, 34-35 (1992). See generally Ted Schneyer, Professional Discipline for Law Firms?, 77 CORNELL L. REV. 1 (1991) (studying the regulation of lawyers in the current legal climate).

7. See Ted Schneyer, Professional Discipline for Law Firms?, 77 CORNELL L. REV. 1, 13 (1991) (proposing the creation of ethical norms for law firms as a whole, rather than for individual lawyers).

8. Professor Schneyer uses five well-published incidents involving large law firms to illustrate how misconduct may not be attributable to the conduct of individual lawyers. Id. at 4-5.

9. Id. at 10 .

10. Id. at 14 .

11. The Festschrift for Ted Schneyer examined his many contributions, focusing on Lawyer Regulation for the 21st Century. See Bruce A. Green, Foreword-The Legal Ethics Scholarship of Ted Schneyer: The Importance of Being Rigorous, 53 ARIZ. L. REV. 365, 365 (2011) (examining Schneyer's many contributions to lawyer regulation in the 21 st century).

12. N.Y. RULES OF PROF'L CONDUCT R. 5.1 (2013); see also Julie Rose O'Sullivan, Professional Discipline for Law Firms? A Response to Professor Schneyer's Proposal, 16 GEO. J. LEGAL ETHICS 1, 2 (2002) (providing background on firm discipline proposals).

13. See Thomas D. Morgan, The Rise of Institutional Law Practice, 40 HOfSTRA L. ReV. 1005, 1005-07 (2012) (examining the rise in institutional practice and the importance of organizational controls). 
firm systems and controls, Professor Schneyer's work may have also contributed to regulators' and jurists' willingness to rely on the state versions of ABA Model Rule of Professional Conduct 5.1, which requires that a partner in a law firm "make reasonable efforts to ensure that the firm has in effect measures giving reasonable assurance that all lawyers in the firm conform to the Rules of Professional Conduct." ${ }^{14}$ Although there are relatively few disciplinary cases citing Rule 5.1(a), opinions increasingly refer to the importance of firm managers making reasonable efforts to ensure that all lawyers in the firm comply with the ethics rules. ${ }^{15}$

In the United States, other scholars relied on Professor Schneyer's work that called for law firms to focus more on fortifying their ethical infrastructure. ${ }^{16}$ Some examined the implementation and impact of ethics systems and controls. ${ }^{17}$ A few have called for more research examining the role of ethical infrastructure. ${ }^{18}$

Outside the United States, commentators and bar leaders joined the chorus by seriously considering the role of ethical infrastructure in influencing lawyer conduct. ${ }^{19}$ This examination has informed regulatory changes in both the United Kingdom and Australia.

In the United Kingdom, the Solicitors Regulation Authority (SRA) has shifted to outcomes-based regulation that focuses on high-level principles and outcomes that drive the provision of legal services to consumers. ${ }^{20}$

14. Model Rules of Prof'l Conduct R. 5.1(a) (2013); see Susan Saab Fortney, Am I My Partner's Keeper? Peer Review in Law Firms, 60 U. COLO. L. ReV. 329, 348-58 (1995) (providing a discussion of Model Rule 5.1(a) and a partner's duty to monitor or supervise other firm lawyers).

15. See Joan C. Rogers, Law Partners and Managers Must Be Active Overseers of Colleagues' Conduct, 28 ABA/BNA LAWYERS' MANUAL ON PROF'L CONDUCT, CURRENT REPORTS 71 (Feb. 1, 2012), available at www.bna.com/law-partners-managers-n12884907572/ (commenting on the responsibility of law firm managers and cases applying ABA Model Rules 5.1(a), 5.3, and the comparable Restatement of Law Governing Lawyer sections).

16. See Alex B. Long, Whistleblowing Attorneys and Ethical Infrastructures, 68 MD. L. REV. 786, 788-89 (2009) (recommending that firms adopt procedures to promote internal reporting of ethics concerns and providing formal protections against retaliation for reporting).

17. See Susan Saab Fortney \& Jett Hanna, Fortifying a Firm's Ethical Infrastructure: Avoiding Legal Malpractice Claims Based on Conflicts of Interest, 33 ST. MARY'S L.J. 669, 690 (2002) (describing the various systems that firms employ to check the quality of their ethics systems).

18. See Elizabeth Chambliss \& David B. Wilkins, Promoting Effective Ethical Infrastructures in Large Law Firms: A Call for Research and Reporting, 30 HOFSTRA L. REV. 691, 693 (2002) (explaining the importance of having a sound ethical infrastructure in place).

19. See, e.g., Christine Parker et al, The Ethical Infrastructure of Legal Practice in Larger Law Firms: Values, Policy and Behavior, 31 U. NEW SOUTH WALES L.J. 158, 159 (2008) (stating how ethical behavior effects the entire firm and not just individual lawyers).

20. See Outcomes-Focused Regulation, SOLIC. REG. AUTHORITY, http://www.sra.org.uk/ solicitors/freedom-in-practice/outcomes-focused-regulation.page (last visited Mar. 19, 2014) (noting that outcomes-focused regulation "replaces a detailed and prescriptive rulebook with a targeted, risk- 
The SRA Authorization Rules now require firms to appoint compliance personnel to oversee risk management and governance matters. ${ }^{21}$ These compliance officers are responsible for ensuring that their firms implement systems and controls to enable firm members to meet the requirements set forth in the Solicitors Handbook. ${ }^{22}$ In describing effective compliance arrangements, the SRA urges solicitors to consider the infrastructure of the firm. ${ }^{23}$

In adopting a form of management-based firm regulation, Australian jurisdictions have taken a somewhat different approach in addressing organizational controls and consumer protection. ${ }^{24}$ Legislators in the state of New South Wales (NSW) in Australia first took the pioneering step of integrating the concept of "ethical infrastructure" into the statute, allowing legal practitioners to incorporate their law practices with no restrictions on non-lawyer ownership. ${ }^{25}$

based approach concentrating on the standards of service to consumers"); see also Susan Saab Fortney, Assessing How Lawyers Keep Their Own Houses Clean: Baseline Report on Outcomes-Focused Regulation, JOTWELL (Feb. 21, 2013), http://legalpro.jotwell.com/assessing-how-lawyers-keep-their-ownhouses-clean-baseline-report-on-outcomes-focused-regulation/ (reviewing an extensive report on the outcomes-based regulation in the UK).

21. See Outcomes-Focused Regulation at a Glance, SOlIC. REg. AUTHORITY, http://www.sra.org.uk/solicitors/freedom-in-practice/OFR/ofr-quick-guide.page (updated Oct. 10, 2011) (explaining that the new method allows for greater flexibility while also providing better care to consumers).

22. See id. (detailing the requirements and responsibilities of the compliance officers).

23. Id.; see Gerard Starkey, Law Firm Name First Compliance Officers for New Regulatory Regime, LEGAL WK. (Jan. 11, 2013), http://www.legalweek.com/legal-week/news/2235368/lawfirms-name-first-compliance-officers-as-sra-pushes-on-with-new-regulatory-regime (stating that compliance officers are "the key SRA contact point at their law firms, taking responsibility for systems and controls and ensuring risk is appropriately managed"); see also Compliance Officers, THE L. SOC'Y (May 2, 2013), http://www.lawsociety.org.uk/advice/articles/compliance-officers/ (explaining "the role of compliance officers").

24. See Steven Mark \& Georgina Cowdroy, Incorporated Legal Practices-A New Era in the Provision of Legal Services in the State of New South Wales, 22 PENN ST. INT'L L. REV. 671, 671 (2004) (detailing the legislation that made the new management-based firm regulations possible). See generally Steve Mark, Regulating For Professionalism: The New South Wales Approach, OFF. OF THE LEGAL SERVS. COMMISSIONER (NSW) (Aug. 2010), http://www.americanbar.org/content/ dam/aba/events/ethics_2020/steve_mark_posting.authcheckdam.pdf (discussing the potentially competing interests of regulation and professionalism).

25. Steven Mark, Regulating For Professionalism: The New South Wales Approach, OFF. OF THE LEGAL SERVS. COMMISSIONER (NSW) 9-11 (Aug. 2010), http://www.americanbar.org/content/ dam/aba/events/ethics_2020/steve_mark_posting.authcheckdam.pdf. Other states in Australia have enacted similar legislation requiring that incorporated firms implement AMS and appoint a legal practitioner director who becomes responsible for the firm's ethical infrastructure. See Incorporated Legal Practices and Multi-Disciplinary Partnerships, LeGAL SERVS. COMMISSION, http://www.lsc.qld. gov.au/compliance/incorporated-legal-practices/appropriate-management-systems (last visited Mar. 19, 2014) (providing an overview of the regulatory framework in Queensland). 
To allay concerns related to non-lawyer ownership and limited liability, the statute imposes a number of management and practice safeguards. ${ }^{26}$ First, the incorporated legal practice (ILP) must appoint a legal practitioner director to be "generally responsible for the management of legal services provided" by the ILP. ${ }^{27}$ Second, the statute provides that the legal practitioner director must ensure that "appropriate management systems are implemented and maintained to enable the provision of those legal services in accordance with . . obligations imposed by [law]." 28

Because the statute did not define "appropriate management systems" (AMS), Steve Mark, the Legal Services Commissioner for NSW, worked with various stakeholders to develop "ten objectives of sound legal practice." 29 The Office for the Legal Services Commissioner (LSC) also devised an "education toward compliance" approach in which the ILP must complete a self-assessment process (SAP). ${ }^{30}$ In this SAP, ILPs complete a Self-Assessment Form (SAF), reporting on their compliance with each of the ten objectives. ${ }^{31}$

Professor Ted Schneyer credits the NSW program with giving content to the term "ethical infrastructure" by "identifying ten types of recurring problems that infrastructure should be designed to prevent or at least mitigate." 32 Because the "education toward compliance" approach focuses

26. Ted Schneyer, Thoughts on the Compatibility of Recent U.K. and Australian Reforms with U.S. Traditions in Regulating Law Practice, 2009 PROF. LAW. 13, 31 (referring to concerns related to non-lawyer ownership and limited liability).

27. Steven Mark \& Georgina Cowdroy, Incorporated Legal Practices-A New Era in the Provision of Legal Services in the State of New South Wales, 22 PENN ST. INT'L L. REV. 671, 681 (2004) (outlining the roles and responsibilities of the solicitor director).

28. See id. at 686 (explaining the strict compliance regulations to which the practitioner director must adhere).

29. See id. at 689-90 (listing the objectives of the education towards compliance strategy).

30. See id. at 689 (stating that the ILPs must demonstrate that they have a program in place that is congruent with the ten objectives previously described).

31. See id. at 691 (explaining that the SAF requires the legal practitioner director to evaluate firm practices and rate management systems using a template). If the completed form indicates that a firm is non-compliant or partially compliant, a staff member with the LSC provides the ILP written guidance and requests confirmation of steps to achieve compliance. See id. (recognizing that the selfassessment form is a required element of the ILP review program); see also Susan Fortney \& Tahlia Gordon, Adopting Law Firm Management Systems to Survive and Thrive: A Study of the Australian Approach to Management-Based Regulation, 10 ST. THOMAS L.J. 152, 152 (2012) (highlighting Tahlia Gordon's contributions as the Research and Project Manager for the Office of the Legal Services Commissioner for NSW).

32. Ted Schneyer, On Further Reflection: How "Professional Self-Regulation" Should Promote Compliance with Broad Ethical Duties of Law Firm Management, 53 ARIZ. L. REV. 576, 585 (2011). Professor Schneyer also expanded on the description of "ethical infrastructure," noting that it consists of "policies, procedures, systems, and structures-in short, the 'measures' that ensure lawyers 
on prevention and mitigation, Professor Schneyer describes the NSW program as a prototype for "proactive, management based regulation." 33 Unlike reactive regulation that disciplines lawyers for violating particular rules, the management-based objectives address the principles of sound practice. ${ }^{34}$ In addition, the SAF provides strategies to address concerns that commonly result in complaints against practitioners. ${ }^{35}$

The proactive approach to regulation has captured the attention of a number of commentators and researchers. ${ }^{36}$ Notably, in 2008, Dr. Christine Parker conducted an empirical study assessing the impact of the NSW program on the number of complaints relating to ILPs. ${ }^{37}$ The study found that rate of complaints for ILPs went down by two-thirds after the ILP completed its initial self-assessment. ${ }^{38}$ Another noteworthy finding was that the rate of complaints for ILPs that completed the SAP was one-third of the number of complaints registered against nonincorporated legal practices. ${ }^{39}$ The researchers recommended further investigation utilizing other research methods because the rate of complaints largely reflected consumer service issues and did not address other ethics concerns, such as duties to the court and other ethical issues that are of less concern to clients. ${ }^{40}$

To obtain more data on the impact of the AMS and the SAP and to identify possible measures to improve management-based regulation of firms, I conducted a mixed method study in 2012, combining a survey

in their firm comply with their ethical duties and that non-lawyers associated with the firm behave in a manner consistent with the lawyers' duties." Id.

33. Id. at 584 .

34. Susan Fortney \& Tahlia Gordon, Adopting Law Firm Management Systems to Survive and Thrive: A Study of the Australian Approach to Management-Based Regulation, 10 ST. THOMAS L.J. 152, 161 (2012) (providing fluid guidelines as opposed to specific rules that were previously used).

35. See id. at 162 (explaining the rudimentary nature of the self-assessment form); see also SelfAssessment Process, OFF. OF LEGAL SERVS. COMMISSIONER, http://www.olsc.nsw.gov.au/ agdbasev $7 \mathrm{wr} / \mathrm{olsc} /$ documents/pdf/self_assessment_form_january2014. pdf (last visited Mar. 19, 2014) (providing access to the SAF).

36. See Christine E. Parker, Tahlia Gordon, \& Steve A. Mark, Regulating Law Firm Ethics Management: An Empirical Assessment of the Regulation of Incorporated Legal Practices in NSW, 37 J.L. SOC'Y 466, 469 (2010) (arguing that ethical regulation within the legal profession must focus on law firms at large rather than exclusively on individual lawyers).

37. See id. at 466 (presenting an evaluation of the management-based regulation scheme).

38. See id. at 483, 485 (analyzing the SAFs and complaints data relating to 620 ILPs).

39. See id. at 488 (explaining that the improvement was "statistically significant at the highest level"). On a third hypothesis that related to levels of implementation of AMS, the researchers found little evidence that the actual rating that firms gave themselves for implementation of management systems made a difference in the number of complaints. See id. at 491 (emphasizing the important role that the self-assessment process has in reducing the complaints rates).

40. See id. at 498 (suggesting areas of further research to better understand the results). 
with interviews. Another article analyzes survey findings related to the implementation and development of AMS, as well as the effects of the SAP. ${ }^{41}$ This Article draws on those findings, focusing on the value of ethics audits in improving ethical conduct by lawyers.

Part I of this Article describes the hypotheses and methodology used in the study. Part II summarizes pertinent survey findings relating to the effects of AMS and the SAP. Part III identifies steps that can be taken to encourage lawyers and their firms to engage in self-assessment. The conclusion explains the foundational role that ethics assessments can play in reducing lawyers' liability while improving the delivery of legal services.

\section{PART I - RESEARCH QUESTIONS AND METHODOLOGY}

For the study, the primary research questions were: (1) what is the relationship between the self-assessment and the ethical norms, systems, conduct, and culture in firms, and (2) how can the SAP be improved? To answer these questions, I conducted a mixed method study in collaboration with the Office of the Legal Services Commissioner for NSW (LSC).

In phase one, I obtained survey data using an online questionnaire. ${ }^{42}$ The questionnaire sought information on approaches, perspectives, effects, and experiences related to the AMS implementation and the SAP. ${ }^{43}$ The target group for the survey consisted of 356 ILPs with two or more solicitors. ${ }^{44}$ A total of 141 directors with ILPs completed the questionnaire, resulting in a response rate of $39.6 \% .{ }^{45}$ The respondents

41. See Susan Fortney \& Tahlia Gordon, Adopting Law Firm Management Systems to Survive and Thrive: A Study of the Australian Approach to Management-Based Regulation, 10 ST. THOMAS L.J.

152, 155 (2012) (examining the relationship between self-assessment procedures and the ethical culture in firms).

42. Susan Fortney, InCorporated Legal Practice Survey, Questionnaire, at 1 (2012) (on file with the St. Mary's Law Journal); see also Susan Fortney \& Tahlia Gordon, Adopting Law Firm Management Systems to Survive and Thrive: A Study of the Australian Approach to Management-Based Regulation, 10 ST. THOMAS L.J. 152, 168 (2012) (indicating that the questionnaire contained thirty-one multipart items, space for text entries, and a section for additional comments).

43. Susan Fortney, Incorporated Legal Practice Survey, Questionnaire, at 1 (2012) (on file with the St. Mary's Law Journal).

44. See Susan Fortney \& Tahlia Gordon, Adopting Law Firm Management Systems to Survive and Thrive: A Study of the Australian Approach to Management-Based Regulation, 10 ST. THOMAS L.J. 152, 168-69 (2012) (specifying that only ILPs that were incorporated between January 1, 2007 and January 1, 2011 were invited to participate in the survey).

45. See id. at 168-70 (discussing the development of the methodology, the response rate, and bias). 
represented firms of varying sizes. ${ }^{46}$

In the second stage of the study, we interviewed directors from ILPs with two or more solicitors. ${ }^{47}$ Maxine Evers, Senior Lecturer at the University of Technology in Sydney, conducted approximately half of the interviews. We systematically pulled the names of firms and invited designated directors from those firms to participate in interviews. ${ }^{48}$ Interview questions allowed for follow-up on issues covered in the questionnaire. The interviews also provided an opportunity to explore in more detail the directors' experiences with implementing AMS and completing the SAP as well as their opinions on improving the SAP and the regulation of firms. ${ }^{49}$ Respondents were advised that the study was being conducted in cooperation with the LSC and were informed of steps taken to protect the anonymity of their responses. ${ }^{50}$

\section{PART II - SELECT SURVEY FINDINGS}

A number of survey items addressed the following question: What is the relationship between self-assessment and the ethical norms, systems, conduct, and culture in firms? ${ }^{51}$ One question specifically asked respondents to note the steps taken after the firm's first completion of the SAP. The majority (71\%) indicated that they revised firm systems, policies, and procedures and $47 \%$ reported that they actually adopted new

46. See Susan Fortney, InCorporated Legal Practice SurVey, Results, at Question 1 (2012) (on file with the St. Mary's Law Journal) (reporting the following categories for respondent firms by size: 1-2 solicitors (10\%), 3-9 solicitors (78\%), 10-19 solicitors (7\%), and 20 or more solicitors (5\%)). Geographically, the respondents were close to evenly divided between firms with home offices in Sydney and firms with home offices in other communities in NSW.

47. See Susan Fortney \& Tahlia Gordon, Adopting Law Firm Management Systems to Survive and Thrive: A Study of the Australian Approach to Management-Based Regulation, 10 ST. THOMAS L.J. 152, 168 (2012) (explaining that limiting the study in this manner would yield "data on the impact of the AMS and SAP on firm dynamics").

48. We continued to systematically pull names and invite respondents until we had over forty individuals who agreed to be interviewed.

49. Although each interviewer followed a four-page interview template, the session allowed for follow-up discussion of issues and concerns that arose during the interview.

50. Steps included scrubbing transcripts so that they did not include any identifying information. Susan Fortney \& Tahlia Gordon, Adopting Law Firm Management Systems to Survive and Thrive: A Study of the Australian Approach to Management-Based Regulation, 10 ST. THOMAS L.J. 152, 168 (2012).

51. See, e.g., Susan Fortney, InCORPorated Legal Practice SuRVEy, Questionnaire, at Question 12-13 (2012) (on file with the St. Mary's Law Journal) (asking what steps the interviewer took upon completion of the SAP and whether certain aspects of the firm culture changed as a result). 
systems, policies, and procedures. ${ }^{52}$ Forty-two percent indicated that they "strengthened firm management" following the completion of the first SAF. ${ }^{33}$ For most steps taken by firms in connection with the SAP, there was no significant difference related to firm size and the steps taken. ${ }^{54}$ Analyzed together, these results and others suggest that the SAP contributed to firms of all sizes taking steps to fortify the firms' ethical infrastructures. ${ }^{55}$

Results also indicate that the SAP was an educational experience for the majority of respondents. Sixty-two percent indicated that they agreed or strongly agreed with the following statement: the self-assessment process "was a learning exercise that enabled our firm to improve client service." 56 Only 15\% disagreed or strongly disagreed. ${ }^{57}$ These responses and text entries indicate that the education toward compliance approach works in providing firm directors the incentives, tools, and authority to take steps to improve the delivery of legal services. A smaller percentage of respondents noted that the SAP enhanced awareness of ethics issues. ${ }^{58}$

To obtain additional information on the extent of the impact of the SAP, a multi-part inquiry asked respondents to rate impact on the following scale: (1) "no impact," (2) "some impact," and (3) "high impact." 59 For analysis purposes, I grouped the responses in four categories: management, client/professionalism concerns, ethics concerns, and firm dynamics. The following graphic sets forth the average ratings for items in these categories. ${ }^{60}$

52. Id. at Question 12.

53. Id.

54. See id. at Question 1, 12 (noting that this figure is based on a cross-tabulation of Questions 1 and 12). When it came to implementation of training following the self-assessment process, there was a trend in which larger firms reported that they implemented training more than smaller ones. Id. at Question 12.

55. See Susan Fortney \& Tahlia Gordon, Adopting Law Firm Management Systems to Survive and Thrive: A Study of the Australian Approach to Management-Based Regulation, 10 ST. THOMAS L.J. 152, 173 (2012) (outlining various steps that firms reported taking following the first selfassessment).

56. See Susan Fortney, Incorporated Legal Practice Survey, Results, at Question 19 (2012) (on file with the St. Mary's Law Journal) (noting that 55\% of respondents checked that they "agree" with the statement and 7\% reported that they "strongly agree" with the statement).

57. See id. at Question 19 (reporting that $11 \%$ of respondents checked that they "disagree" with the statement and $4 \%$ reported that they "strongly disagree" with the statement).

58. See id. at Question 19 (reporting that approximately 45\% of respondents "agree" or "strongly agree" that SAP enhanced ethics awareness).

59. Id. at Question 13.

60. See id. (indicating a trend in which directors at smaller firms reported that the selfassessment process impacted supervision at a higher rate than that reported by directors at larger 


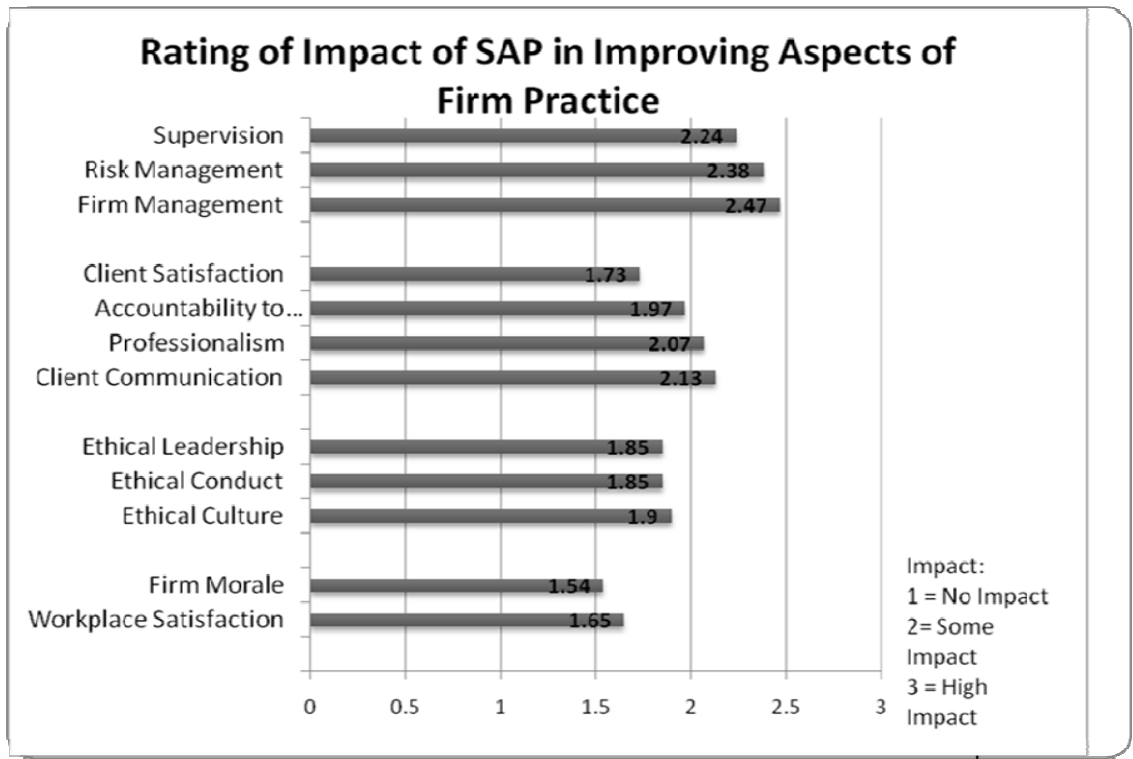

As indicated by the results summarized in the graphic, the largest percentage of respondents reported that the greatest impact was on matters related to firm management and risk management, followed by impact on client service matters. The respondents' ratings of the impact on general ethics concerns and firm dynamics were lower. These results can be attributed to the fact that the items covered in the SAF largely deal with practice management issues that commonly result in firm concerns related to client complaints, such as cost disclosure and fee recovery.

Although many of the items covered in the SAF relate to proper conduct under applicable law, the aggregate results suggest that respondents did not perceive that the SAP impacted ethics conduct, leadership, and culture as much as management and client service issues. This conclusion is supported by other responses indicating that a smaller percentage of firms are implementing measures related to general ethics concerns, as opposed to measures and controls that the SAF expressly covers. ${ }^{61}$ Similarly, more respondents report that their firms implemented

firms). This is based on a cross-tabulation between the responses to Questions 1 and 13. See id. (excluding this finding, there was no significant difference between the impact reported by respondents and firm size).

61. For example, only $37 \%$ of the respondents indicated that their firms did not have a director or committee appointed to direct ethics initiatives. Id. at Question 28. By comparison, 76\% of 
measures specifically described in the SAF, but a smaller number of respondents used controls not described in the SAF. ${ }^{62}$

These results point to an overarching question related to the effect of the SAP. Does the process contribute to serious examination of firm practices, policies, and systems, or does the SAP result in firms using the SAF as a checklist, simply implementing the specific practices, policies and procedures described in the SAF? Even worse, does the SAP result in a meaningless box checking exercise in which directors simply go through the SAF checking that their firms are "compliant" without serious examination of firm practices? In the survey, $12 \%$ of respondents agreed with the statement that the SAP amounted to meaningless "box ticking." 63

In evaluating survey responses and interview results, directors' experiences and perspectives appear to fall on a continuum. At one end, a relatively small percentage of respondents may be simply checking boxes and reporting that their firms are compliant without actual review of firm policies. ${ }^{64}$ The mid-continuum point is represented by the large percentage of respondents who report that they used the SAF as a learning process to review and revise existing policies, as well as adopt new ones. ${ }^{65}$ At a minimum, these firm representatives are addressing those matters that are expressly described in the SAF form. ${ }^{66}$ At the far end of the continuum are those firm respondents who have been inspired by the SAF to take management systems to the next level. ${ }^{67}$ These respondents recognize the business imperative in adopting management systems to

respondents reported that their firms had appointed a director or committee to handle risk management. Id.

62. See id. at Question 24 (illustrating the fact that $92 \%$ of respondents indicated that their firms had a practice for verifying credentials and certifications of all practitioners, a supervisory control identified in the SAF). On the other hand, only $66 \%$ reported that their firms made a regular practice of having a director (not involved in the representation) periodically review all current files. Id.

63. See id. at Question 18 (finding that $66 \%$ of respondents disagreed that "SAP amounts to meaningless box ticking," while $22 \%$ neither agreed nor disagreed).

64. See Susan Fortney \& Tahlia Gordon, Adopting Law Firm Management Systems to Survive and Thrive: A Study of the Australian Approach to Management-Based Regulation, 10 ST. THOMAS L.J. 152,170 (2012) (suggesting the existence of a potential bias in the survey because directors could be concerned about what their responses would reveal).

65. See Susan Fortney, Incorporated Legal Practice Survey, Results, at Question 18 (2012) (on file with the St. Mary's Law Journal) (demonstrating that $55 \%$ of survey takers believed that the SAP was useful as a learning exercise).

66. See id. (noting that $56 \%$ of respondents believed that adopting the AMS "reduced the firm's professional liability of risk").

67. See id. (revealing that $7 \%$ of those surveyed strongly agreed that the SAP was a positive learning tool). 
make their firms more competitive in attracting and retaining clients. ${ }^{68} \mathrm{~A}$ small group of respondents who recognize the value of management systems are going beyond the minimum required by the SAF and seeking a Quality Management Certification under the guidelines adopted by the International Organization for Standards. ${ }^{69}$ Firms might use such certifications to distinguish themselves for business development purposes.

\section{PART III - INTEGRATING MANAGEMENT-BASED PRINCIPLES}

The research findings discussed above indicate that lawyers' selfassessment makes a real difference in educating lawyers by first evaluating their firm practices, and second, by developing systems. As revealed by respondents' reports of the impact of the SAP, the greatest impact was on firm management, risk management, and supervision. The survey findings relating to the dramatic decrease in the number of complaints suggest that lawyers can reduce their exposure for liability for disciplinary complaints by evaluating firm practices and improving firm controls. ${ }^{70}$ These findings may capture the attention of some practitioners, contributing to them going through the SAP.

Although the data is compelling, most practitioners may need additional incentives or a push to get them to devote the time to seriously examining firm processes. In Australia, the regulatory implementation of legislation mandating that incorporated firms implement appropriate management systems requires designated practitioners to complete the SAP. ${ }^{71}$ Opinions reported in my study revealed that a number of the respondents questioned or even opposed being required to complete an

68. See id. (showing that a total of $62 \%$ of respondents believed that the SAP enables their firm to improve client service).

69. See id. at Question 14 (surveying benefits incurred by the SAP); see also Certification To ISO Management System Standard, INT'L. ORG. FOR STANDARDIZATION, http://www.iso.org/ iso/home/standards/certification.htm (last visited Mar. 19, 2014) (describing some of the certifications that use the ISO standards and differentiating between ISO standards and autonomous certification groups); Law 9000 Legal Best Practice, SAI GLOBAL, https://www.saiglobal.com/ assurance/legal-best-practice/LAW9000.htm (last visited Mar. 19, 2014) (exemplifying a certification system for legal practices).

70. See id. at Question 18 (revealing that $40 \%$ of respondents agreed or strongly agreed that "AMS reduced the number of client complaints," versus only $19 \%$ disagreeing or strongly disagreeing that client complaints had gone down).

71. See Susan Fortney \& Tahlia Gordon, Adopting Law Firm Management Systems to Survive and Thrive: A Study of the Australian Approach to Management-Based Regulation, 10 ST. THOMAS L.J. 152, 171 (2012) (explaining the regulation in Australia where a designated practitioner must complete the SAP). 
SAF. ${ }^{72}$ Thirty-three of the 137 responding critics indicated that their opinions changed following completion of the SAP. ${ }^{73}$ This experience points to the importance of taking steps to encourage lawyers to examine their practices as part of a risk management and practice improvement program.

The steps taken may depend on a variety of factors, including the state's disciplinary procedures, bar programs, and insurer support for risk management initiatives. Progressive regulators, insurers, and bar leaders who find data to be persuasive should be more willing to take steps to encourage lawyers to engage in self-examination of firm practices and systems. The following discussion considers specific steps that can be taken to spur lawyers and firms to systematically examine their practices and controls.

\section{A. Regulatory Mandate Related to Alternative Business Structures}

Outside of Australia, other jurisdictions are now seriously considering regulatory reforms, including risk-based approaches to regulation. Regulators in a number of Canadian provinces are exploring regulatory reforms and studying the experiences in England and Australia. ${ }^{74}$ For example, the Director of Professional Responsibility for the Nova Scotia Barristers' Society recommends that the Council for the Nova Scotia Barristers' Society consider the following changes:

[A]dopting a proactive approach with lawyer and law firms through education, engagement, the creation of an appropriate management systemsbased approach, and the provision of tools and training to help firms of all sizes practice ethically and competently in the public interest and develop an embedded ethical infrastructure ... [and] allowing firms the room to establish appropriate management systems that suit the nature of their clientele and to demonstrate their effectiveness, then refocus our attention and resources on supporting sole practitioners and small firms in achieving appropriate management systems and avoiding problems ... ${ }^{75}$

72. See Susan Fortney, InCorporated Legal Practice Survey, Results, at Question 22 (2012) (on file with the St. Mary's Law Journal) (demonstrating the opinions of respondents regarding the required $\mathrm{SAP})$.

73. See id. at Question 9 (soliciting respondents' opinions on concerns regarding the SAP).

74. See The Law Soc'y of Upper Canada, Professional Regulation Committee REPORT, REPORT TO CONVOCATION, at 432-36 (2013), available at http://www.lsuc.on.ca/WorkArea/DownloadAsset.aspx?id=2147495044 (summarizing different approaches used in Australia, the United Kingdom, the United States, and Canada).

75. Victoria Rees, Transforming Regulation and Governance in the Public Interest, NOVA SCOTIA BARRISTERS' SOC'Y 51 (Oct. 15, 2013), available at http://nsbs.org/sites/default/files/cms/news/ 
This excerpt from the report suggests that regulators in other countries recognize the value of a proactive "education toward compliance" approach that encourages lawyers and their firms to improve their management systems. ${ }^{76}$ As these regulators study the possibility of relaxing prohibitions on alternative business structures, management-based principles may be a feature of the new regulatory regime. This is similar to the approach used in Australia where the new regulatory approach and SAP evolved out of the legislation lifting restrictions on non-lawyer ownership of incorporated legal practices. ${ }^{77}$

After other jurisdictions join the United Kingdom and Australia in allowing non-lawyer ownership of law firms, the American Bar Association ("ABA") and state regulators may revisit modifying disciplinary rules that prohibit non-lawyer ownership of law firms. ${ }^{78}$ Any changes in the current rules will need to address the critics who argue that non-lawyer ownership will undermine core values of the legal profession and public protection. ${ }^{79}$ Except for the staunchest critics of changing current prohibitions, the reservations of some might be addressed by requiring that safeguards be implemented at firms with non-lawyer owners. These controls could include requiring that the firms appoint a general counsel and demonstrate that the firm has in place proper management systems to give reasonable assurance that firm lawyers act in accordance with their professional obligations.

\section{B. Use of Management-Based Approaches As an Alternative to Discipline}

Given the strong opposition to allowing non-lawyer ownership of law firms in the United States, it may be many years until the restrictions on

2013-10-30transformingregulation.pdf.

76. Id. at 62 (quoting Amy Salyzn, What if We Didn't Wait? Promoting Ethical Infrastructure in Canadian Law Firms, SLAW (Jul. 25 2013) available at http://www.slaw.ca/2013/07/25/what-if-wedidnt-wait-promoting-ethical-infrastructure-in-canadian-law-firms/).

77. See id. at 37 (summarizing Australian legal ownership regulations, which allow non-lawyers to have co-ownership of law firms).

78. In 2012, the ABA Commission on Ethics 20/20 considered proposing a limited form of non-lawyer ownership in law firms, but decided to remove the idea following strong opposition. Debra Cassens Weiss, ABA House Postpone Resolution Reaffirming Opposition to Nonlawyer Ownership of Law Firms, A.B.A. J. (Aug. 6, 2012, 10:26 AM), http://www.abajournal.com/ news/article/resolution_confirms_aba_stance_against_nonlawyer_ownership_of_law_firms/.

79. See id. (describing the votes to close the resolution); see also James D. Moliterno, The Trouble with Lawyer Regulation, 62 EMORY L.J. 885, 866-87 (2013) (critiquing the "backward looking" and "self-preserving" perspectives of lawyers who oppose non-lawyer ownership of law firms). 
non-lawyer ownership are changed. ${ }^{80}$ Until that time, there are other opportunities for integrating management-based principles into the regulation of lawyers. One avenue that is currently employed in many states is to use diversion programs as an alternative to discipline. ${ }^{81}$ After reviewing the genesis of these programs and the approach used in current diversion programs, this section discusses the value of broader use of diversion programs to deal with minor misconduct and practice management concerns.

Over forty years ago, a Special Committee on Evaluation of Disciplinary Enforcement, chaired by former U.S. Supreme Court Justice Tom Clark, issued a report analyzing problems related to disciplinary enforcement ("the Clark Report"). ${ }^{82}$ The Clark Report noted that one deficiency was that disciplinary procedures failed to address matters involving minor misconduct. 83

Twenty years later, the ABA's Commission on the Evaluation of Disciplinary Enforcement, chaired by Robert McKay ("the McKay Commission"), issued a report that addressed the need for procedures to deal with minor misconduct and the need to provide practice management guidance to lawyers. ${ }^{84}$ The McKay Commission recommended the establishment of Law Practice Assistance Committees to consider cases referred to the committees and to aid lawyers voluntarily seeking

80. James D. Moliterno, The Trouble with Lawyer Regulation, 62 EMORY L.J. 885, 903 (2013) (asserting that "lawyer-dominated legislatures" and "professional resistance" will likely stymie statutory changes that allow for non-lawyer ownership and Alternative Business Structures).

81. See ARIZONA ATtOrNEy Diversion GUIDELINES AdOPTED BY THE ARIZONA SUPREME COURT, AZ. BAR (2011), available at http://www.azbar.org/media/66357/diversion $\% 20$ guidelines\%20effective\%2001-01-11.pdf (outlining the guidelines for the diversion program in Arizona); see also Diane M. Ellis, Is Diversion A Viable Alternative to Traditional Discipline?: An Analysis of the First Ten Years in Arizona, PROF. LAW., Fall 2002, at 1 (discussing the diversion program in Arizona).

82. ABA Special Comm. on Evaluation of Disciplinary Enforcement, Problems AND RECOMMENDATIONS IN DiSCIPLINARY ENFOREMENT, FinAl DRAFT (1970), available at http://www.americanbar.org/content/dam/aba/migrated/cpr/reports/Clark_Report.authcheckdam. pdf.

83. See id. at $92-95$ (examining problems associated with the lack of admonitory procedures to deal with minor misconduct). The Clark Report recommended that disciplinary agencies be authorized to issue "informal admonitions in disposing of complaints involving" minor misconduct. Id.; see also Diane M. Ellis, Is Diversion A Viable Alternative to Traditional Discipline?: An Analysis of the First Ten Years in Arizona, PROF. LAW., Fall 2002, at 1, 4 (discussing the key concerns related to the lack of admonitory procedures).

84. ABA SPECial COMM. ON EVAluation of Disciplinary ENFORCEMENT, LAWYER REGULATION FOR A NEW CENTURY (1992), available at http://www.americanbar.org/ groups/professional_responsibility/resources/report_archive/mckay_report.html. 
assistance. ${ }^{85}$ The McKay Commission also recommended that "jurisdictions should adopt procedures in lieu of discipline for matters in which a lawyer's actions constitute minor misconduct, minor incompetence, or minor neglect." 86 As stated in the recommendation, disciplinary counsel and the respondent lawyer may agree to submit the minor misconduct matter to non-disciplinary proceedings that "may consist of fee arbitration, arbitration, mediation, lawyer practice assistance ... or any other non-disciplinary proceedings." 87

Following the McKay Commission Report, the ABA amended their Model Rules for Lawyer Disciplinary Enforcement to expressly provide for alternatives to discipline. ${ }^{88}$ Under the amended rules, alternative discipline is available for instances of "lesser misconduct." 89 Prior to filing

85. See id. at Recommendation 4 ("The Committee should provide guidance to the lawyer including, when appropriate: (a) review of the lawyer's office and case management practices and recommendations for improvement: and (b) review of the lawyer's substantive knowledge of the law and recommendations for further study."). Comments to the recommendation noted that the Committee could provide direct supervision and guidance or recommend other resources such as office management classes or substance abuse counseling. Id.

86. Id. at Recommendation 9.

87. Id.; see also id. at Recommendation 10 (setting forth expedited procedures for handling instances of minor misconduct); Diane M. Ellis, Is Diversion A Viable Alternative to Traditional Discipline?: An Analysis of the First Ten Years in Arizona, PrOf. LAW., Fall 2002, at 1, 4 (explaining that the ABA adopted the McKay Commission recommendations in 1992).

88. Joseph Roszkowski, Hot ABA Annual Meeting Subjects, R.I. B.J., Nov. 1996, at 13, 15 (noting that in 1996, the ABA House of Delegates adopted a resolution adding the alternatives to discipline provisions to Rule 11 of the Model Rules for Lawyer Disciplinary Enforcement). "The Philadelphia Bar Association and the ABA standing Committees on Professional Discipline, Ethics and Professional Responsibility and Lawyers' Responsibility for Client Protection" sponsored the amendment. Conference Draws Record Attendance, PROF. LAW, Aug. 1996, at 20, 24 (reporting on an ABA National Conference on Professional Responsibility panel that discussed how alternatives to discipline best address causes of lawyer incompetence).

89. Rule 9(2) under the ABA Model Rules for Lawyer Disciplinary Enforcement states that "[l]esser misconduct is conduct that does not warrant a sanction restricting the respondent's license to practice law.” MODEL RULES FOR LAWYER DiSCIPLINARY ENFORCEMENT R. 9(2) (2002), available at

http://www.americanbar.org/groups/professional_responsibility/resources/lawyer_ethics_regulation/ model_rules_for_lawyer_disciplinary_enforcement.html. The rule states that conduct shall not be viewed as lesser misconduct if:

(1) the misconduct involves the misappropriation of funds;

(2) the misconduct results in or is likely to result in substantial prejudice to a client or other person;

(3) the respondent has been publically disciplined in the last three years;

(4) the misconduct is of the same nature as misconduct for which the respondent has been disciplined in the last five years;

(5) the misconduct involves dishonesty, deceit, fraud, or misrepresentation by the respondent; 
formal charges, Model Rule of Disciplinary Enforcement R.11 empowers disciplinary counsel to refer matters involving lesser misconduct to the Alternatives to Discipline Program. ${ }^{90}$ As provided in the rule, alternatives to discipline may include "fee arbitration, arbitration, mediation, law office management assistance, lawyer assistance programs, psychological counseling, continuing legal education programs, ethics school or any other program authorized by the court." 91 The rule sets forth factors for determining if a referral is appropriate. ${ }^{92}$ It also describes the mechanics for handling the referral, including notice to complainant and documentation of the terms of the referral in an agreement between the respondent lawyer and disciplinary counsel. ${ }^{93}$ Once a respondent lawyer completes the terms of the agreement with disciplinary counsel, the matter is effectively dismissed. ${ }^{94}$ On the other hand, the matter may proceed through the normal disciplinary channels when respondents decline to participate in the diversion program or fail to fulfill the agreement. ${ }^{95}$

A number of states have amended their disciplinary procedures to provide for alternatives to discipline, including diversion programs. ${ }^{96}$ In these programs, complaints accusing lawyers of minor misconduct are diverted from the disciplinary process to a program where the lawyers may

(6) the misconduct constitutes a "serious crime" as defined in [the Rules];

(7) the misconduct is part of a pattern of similar misconduct. Id.

90. Id. R. 11(7).

91. Id.

92. Id. The pertinent factors deciding whether to refer a respondent are:

(a) whether the presumptive sanction under the ABA Standards for Imposing Lawyer Sanctions for the violations listed in the complaint is likely to be no more severe than reprimand or admonition;

(b) whether participation in the program is likely to benefit the respondent and accomplish the goals set forth by the program;

(c) whether aggravating or mitigating factors exist; and

(d) whether diversion was already tried.

Id. R. 11(7)(3).

93. Id. R. 11(2).

94. See id. R. 11(7)(6) ("[D]isciplinary complaint shall be held in abeyance [dismissed] pending successful completion of the terms of the contract.").

95. See id. R. 11(7)(7)(b) ("A material breach of the contract shall be cause for termination of the respondent's participation in the program ... [and] disciplinary proceedings may be resumed or reinstituted.").

96. See Jennifer Gerarda Brown \& Liana G.T. Wolf, The Paradox and Promise of Restorative Attorney Discipline, 12 NEV. L.J. 253, 264 (2012) (describing how jurisdictions used different methods to resolve less serious complaints). 
obtain guidance, education, and monitoring. ${ }^{97}$ Some form of diversion program currently exists in twenty-four states, plus the District of Columbia. ${ }^{98}$ Although a jurisdiction may narrow the eligibility for a diversion program to lawyers suffering from some impairment, the vast majority of the jurisdictions allow participation by lawyers suffering from impairment or struggling with practice management problems. ${ }^{99}$

A survey of rules for diversion programs reveals that many share common features. ${ }^{100}$ As a starting point, the rules clarify the eligibility for participation in the program. Some states use the term "minor misconduct" to refer to the general category of matters that may be diverted. ${ }^{101}$ Other states describe with more specificity the types of misconduct that may result in diversion. ${ }^{102}$

97. See, e.g., Susie Morgan, When Bad Things Happen to Basically Good Lawyers: LSBA Program Offers "Alternative to Discipline" Assistance, 46 LA. B. J. 388, 388 (1999) (describing the features of the Louisiana State Bar Association (LSBA) program). In Louisiana, the Practice Assistance and Improvement Program has two components: the Diversionary Program and the Attorney/Client Assistance Program. The Diversionary Program handles matters after disciplinary counsel has found misconduct and made a referral to the program. If disciplinary counsel screens a complaint and determines that only minor misconduct has been alleged, but that it does not merit a full investigation, disciplinary counsel may refer the matter to the Attorney/Client Assistance Program, where practice assistance counsel will attempt to facilitate a resolution between the complainant and the respondent. Id. at 389-90.

98. According to an internet search conducted by my research assistant in November 2013, programs exist in the following states: Arizona, Colorado, Delaware, District of Columbia, Florida, Iowa, Kansas, Louisiana, Maryland, Massachusetts, Missouri, Nevada, New Hampshire, New Jersey, New York, North Dakota, Oklahoma, Oregon, Tennessee, Texas, Utah, Washington, and Wyoming. Cf. Leslie C. Levin, The Case for Less Secrecy in Lawyer Discipline, 20 GEO. J. LEGAL ETHICS 1, 4 n.19 (2007) (identifying twenty-two jurisdictions with diversion programs).

99. In New York, three of the four Appellate Divisions have adopted rules allowing for diversion for lawyers suffering from substance abuse or other dependency; " $t]$ he Bellacosa Commission recommended the adoption of a uniform rule by all four departments" in New York. Compare NY State Lawyers Assistance Programs, Diversion Model Rules: Diversion-to-Monitoring rule, NYLAT, http://www.nylat.org/projects/diversionrules/index.html (last visited Mar. 19, 2014) (outlining the recommended rules to the four departments), with NY State Lawyers Assistance Programs, Diversion Model Rules: Comparison Matrix of Diversion Rules, NYLAT, http://www.nylat.org/projects/diversionrules/comparison.html (last visited Mar. 19, 2014) (displaying a comparison chart of the recommended rules and how they have been enacted).

100. The headings in the Missouri diversion rule provide a good overview of the matters commonly covered in diversion rules: the Offer of Diversion, Diversion Program (describing available services), Participation in the Program, Diversion Agreement, Costs of Diversion, Effect of Diversion, Effect of Successful Completion of the Diversion Agreement, Breach of Diversion Agreement, Effect of Rejection of Recommendation for Diversion, and Confidentiality. MO. SUPREME CT. R. 5.105 (2003), available at http://www.courts.mo.gov/courts/ClerkHandbooksP2RulesOnly.nsf/0/ 4db1af73e9e6731386256ca6005216df?OpenDocument.

101. FLA. B. REG. R. 3-5.3 (2004), available at https://www.floridabar.org/divexe/rrtfb.nsf/ FV/A5AD0ADA6E7E8BB285256EA7005EB692 ("Disciplinary cases that otherwise would be disposed of by a finding of minor misconduct or by a finding of no probable cause with a letter of 
In reviewing a complaint, disciplinary counsel or a disciplinary panel may offer the respondent the opportunity to enter the diversion program if they determine that the matter is one that is eligible for diversion. ${ }^{103}$ Under state rules, the voluntary nature of participation by the respondent is a key feature of the diversion program. ${ }^{104}$ The disciplinary counsel and respondent may enter a diversion agreement or contract that specifically sets forth the terms and conditions of the participation. ${ }^{105}$ The rules describe the effect of a respondent successfully complying with terms of the agreement, as well as the consequences for breaching the agreement. ${ }^{106}$ Rules vary in the manner in which they deal with costs associated with participating in the program and the confidentiality of participation in the program. $^{107}$

Although state rules vary in the manner in which they approach diversion, all provide an "intervention" opportunity for lawyers to obtain assistance and deal with issues that may lead to problems in the future. ${ }^{108}$

advice are eligible for diversion to practice and professionalism enhancement programs.").

102. See AZ. BAR, ARIZONA ATTORNEY DiVERSION GUIDELINES ADOPTED BY THE ARIZONA SUPREME COURT, at 1-2 (2011), available at http://www.azbar.org/media/66357/diversion\%20 guidelines\%20effective\%2001-01-11.pdf (describing cases eligible for diversion, as well as cases not eligible for diversion).

103. See, e.g., WASH. CT. R. 6.1 (2014), available at http://www.courts.wa.gov/court_rules/ ?fa=court_rules.display\&group=ga\&set=ELC\&ruleid=gaelc0606.01 (noting that "disciplinary counsel may refer a respondent lawyer to" the diversion program). In some states, a disciplinary committee or panel can later recommend that a matter be diverted. See N.J. R. GOVERNING THE CTS., 1:20-3 (2013), available at http://www.judiciary.state.nj.us/rules/r1-20.htm (authorizing a disciplinary committee chair to request that the Director of the Office of Attorney Ethics divert a matter and approve an agreement in lieu of disciplinary action).

104. See UtAh Jud. COUnCIL RUles OF JUd. AdMIN. R. 14-533 (2013), available at http://www.utcourts.gov/resources/rules/ucja/ch14/05\%20Lawyer\%20Discipline/USB14-533.html (explaining how a respondent may be referred to diversion program).

105. The Utah rule requires that the diversion contract "be supported by the respondent's or the respondent's lawyer's affidavit or declaration" setting forth the purpose for diversion and how the specific terms of the diversion contract will address the allegation raised by the complaint. $I d$.

106. See KAN. SUP. CT. R. 203 (d)(2)(vi-vii) (2010), available at http://www.kscourts.org /rules/rule-list.asp?r1=Rules+Relating+to+Discipline+of+Attorneys (stating that "formal disciplinary procedures will resume" if the respondent fails to complete the diversion program).

107. Many state rules require the respondent to pay for the diversion program. See, e.g., WIS. SUP. CT. R. 22.10 (5) (2013), available at http://www.wicourts.gov/sc/rule/chap22.pdf ("[T]he attorney shall pay all costs incurred in connection with participation in an alternatives to discipline program."); see also id. R. 22.10(8) (noting that all files and records of diversion are confidential).

108. Arthur F. Greenbaum, The Automatic Reporting of Lawyer Misconduct to Disciplinary Authorities: Filling the Reporting Gap, 73 OHIO ST. L. J. 437, 442-43 (2012). Greenbaum explains:

If the system could better identify patterns of behavior that warrant intervention before serious misconduct occurs, and offer remedial training to help solve incipient problems, that would significantly benefit lawyers, clients and the profession. To the extent that the 
Rather than having to deal with misconduct after it occurs, participation in a diversion program advances public protection by preventing problems. ${ }^{109}$

By entering into an individualized diversion agreement, lawyers obtain guidance, support, and tools to meet their particular needs. ${ }^{110}$ Because participation is voluntary, lawyers are likely to be open to recommendations on how to improve their practices. ${ }^{111}$

Long-term diversion saves time and money if the remedial training helps lawyers avoid future misconduct and complaints. ${ }^{112}$ Even in the short term, diversion may cost less than processing a complaint through the formal disciplinary process. ${ }^{113}$

Both disciplinary counsel and respondent counsel have commented on the value of diversion program in protecting the public by helping lawyers change how they practice. ${ }^{114}$ Bar journal articles have discussed the value of diversion programs as an alternative to discipline. ${ }^{115}$

present contraction of the legal market has forced more new lawyers to enter solo practice without expertise or mentors, the need for remedial training will grow.

Id.

109. See Mark A. Armitage, Regulating Competence, 52 EMORY L.J. 1103, 1107 (2003) (urging "courts, discipline agencies, bar associations, and the academy [to] dedicate the time and resources to refine, enhance, and propagate programs aimed at protecting the public from [disciplinary violations] in the first place"). Mark A. Armitage served as Associate Director of the Attorney Discipline Board of Michigan. Id. at 1103 n.*.

110. See Jennifer Gerarda Brown \& Liana G.T. Wolf, The Paradox and Promise of Restorative Attorney Discipline, 12 NEV. L.J. 253, 271 (2012) (“An enormous benefit of such programs is that the diversion contract can be specifically tailored to the respondent's shortcomings to help prevent similar violation in the future.").

111. See id. (suggesting that respondents are more "likely to be agreeable and open to recommendations on how to improve" their practices because they must consent to the diversion agreement).

112. See id. at 273 ("Diversion programs using mediation do facilitate communication between the respondent and the complainant, and the mediation may lead to a resolution more quickly than formal disciplinary proceedings.").

113. See id. at 271 ("Diversion programs are often cheaper and faster than formal grievance hearings.").

114. See, e.g., Linda Acevedo, Grievance Referral Program, How the Texas Disciplinary Counsel's Office Is Helping Lawyers Help Themselves, TEX. B. J., June 2013, at 521, 521 (noting that in six years, the Texas diversion program has "become an integral part of the Texas attorney discipline system" with more than 230 attorneys completing the program and thirty participating in the program at the time the article was written). Mark Harrison, an experienced respondent counsel, noted that $70 \%$ of informal charges could be diverted, rather than formally prosecuted. Diane M. Ellis, A Decade of Diversion: Empirical Evidence that Alternative Discipline Is Working for Arizona Lawyers, 52 EMORY L.J., 1221, 1230 (2003).

115. See Linda Acevedo, Grievance Referral Program, How the Texas Disciplinary Counsel's Office Is Helping Lawyers Help Themselves, TEX. B.J., June 2013, at 521, 521-22 (outlining the benefits of 
One empirical study reported on the impact of the Arizona alternative discipline system. ${ }^{116}$ Using data from a ten-year period, the researchers analyzed the frequency and severity of disciplinary charges filed against lawyers after they successfully completed the diversion program. ${ }^{117}$ To objectively measure the effectiveness of the diversion program, the study compared the frequency and severity of disciplinary "charges filed against lawyers who successfully completed a diversion program, as compared to" the charges against lawyers who declined to participate in a diversion program. ${ }^{118}$ Based on the analysis of the data, the study report concluded that there was "a statistically significant difference in the number and severity of subsequent disciplinary charges between lawyers who [had] completed a . . . diversion program and those who [had] not." 119

Although these findings can be used by proponents who advocate wider use of diversion programs, the study relied only on available records. ${ }^{120}$ This data set may not have reflected the actual number of attorneys who were diverted and had their records expunged because they had not been subject to new complaints for a three-year period following their completion of a diversion program. ${ }^{121}$

the Texas diversion program); Lawyers Helping Lawyers: LSBA Program Offers Alternatives to Discipline, LA. B. J., June 2001, at 50, 50 (“[T]he Louisiana State Bar Association's (LSBA) Practice Assistance and Improvement Program is a resounding success.”).

116. See Diane M. Ellis, A Decade of Diversion: Empirical Evidence That Alternative Discipline is Working for Arizona Lawyers, 52 EMORY L.J., 1221, 1222 (2003) (stating that the study's purpose was "to evaluate the impact diversion has had on Arizona's lawyer regulatory system"). Diane M. Ellis, the Director of the State Bar of Arizona Law Office Management Assistance Program, and member Assistance Program also noted that the information from the study helped State Bar executives evaluate decisions about programs and resources, while giving Lawyer Assistance personnel concrete data to use in designing diversion programs. Id. Ms. Ellis also suggested that the study would help lawyers evaluate whether they should participate in a diversion program and proactively seek management assistance. Id.

117. See id.at 1221 (analyzing "data from the time the State Bar of Arizona's Law Office Management Assistance Program (LOMAP) was established in April 1992 to April 2002”).

118. Id. at 1252 .

119. Id. at 1255. Another finding was that neither "the breadth of [the] assessment [n]or the length of ... participation" by the lawyer appears to be critical, but extensiveness of the terms of the agreement "appear[ed] to have a much clearer link with desirable results." Id. at 1265.

120. Id.

121. In an insightful article examining public access to information on lawyer discipline, Professor Leslie Levin pointed to this limitation in the Arizona diversion study. See Leslie C. Levin, The Case for Less Secrecy in Lawyer Discipline, 20 GEO. J. LEGAL ETHICS 1, 5 (2007) (cautioning that "little is known about how well diversion programs work generally or how well individual diversion options work"). In pointing out limitations in the study, Professor Levin also noted that "the 'control group' against which recidivism rates were compared included lawyers who did not qualify for diversion because their offenses were too serious." Id. at 5 n.26. She also explained that "the study did not account for the how the absence" or existence of prior discipline or the lack thereof 
In order to better assess recidivism by lawyers who complete a diversion program, administrators of these programs should maintain records for a longer period of time, or at least maintain them for statistical purposes. ${ }^{122}$ Such statistical information provides a more complete picture for research, and helps us understand the extent to which diversion experiences impact the manner in which lawyers practice and discharge their responsibilities.

As disciplinary authorities evaluate their current diversion programs or consider establishing new diversion programs, they can take steps to address other public protection issues related to diversion. One such concern relates to whether diversion programs improperly shield lawyers by allowing them to escape formal discipline and a record that would later be an aggravating factor if the lawyer is faced with disciplinary charges. ${ }^{123}$ To deal with this criticism, diversion rules can provide that records related to diversion agreements "remain confidential and not available to the public ... [but that] the information may be considered in any future disciplinary matters" evaluated by disciplinary authorities. ${ }^{124}$

Another consumer concern relates to the treatment of persons whose filed complaints are referred to diversion programs. In discussing the virtues of restorative justice, one commentator explained that diversion programs' emphasis on the rehabilitation and the future may ignore the

affected the disciplinary counsel's evaluation of subsequent complaints. See id. (noting the relevance because expunging the records may contribute to disciplinary counsel assuming that the respondent lawyer had a "clean" record). If lawyers with expunged records receive leniency because disciplinary counsel believe that the lawyers had not previously engaged in questionable conduct, this could skew the numbers related to the impact of diversion is preventing future misconduct. Id.

122. To monitor the recidivism rate of lawyers who successfully complete diversion, Kansas maintains annual statistical records of the number of complaints assigned to the Attorney Diversion Program. See KAN. SUP. CT. R. 203(d)(3)(i) (2010), available at http://www.kscourts.org/rules/rulelist.asp? $\mathrm{r} 1=$ Rules+Relating+to+Discipline+of+Attorneys (specifying that the information should include "the final disposition[], the number of diversion agreements reached, the number of complaints returned to the traditional disciplinary process, and the success or failure of [r]espondents in completing their diversion" programs).

123. See Jennifer Gerarda Brown \& Liana G.T. Wolf, The Paradox and Promise of Restorative Attorney Discipline, 12 NEV. L.J. 253, 271 (2012) (warning that the public may not learn about some repeat offenders who game diversion programs to their advantage).

124. Kansas uses such an approach, noting that successful completion of a diversion program is "reported back to the Review Committee" and will result in the dismissal of the complaint, but in future disciplinary matter the Disciplinary Administrator may consider the information as "prior discipline." KAN. SUP. CT. R. 203(d)(2)(vi) (2010), available at http://www.kscourts.org/rules/rulelist.asp? $1=$ Rules+Relating+to+Discipline+of + Attorneys. In Iowa, upon successful completion of a diversion program, the board dismisses the complaint, the attorney shall not be considered "disciplined, but the attorney's admission of misconduct may be considered in imposing sanctions" if the attorney is later disciplined. R. P. IOWA SUP. CT. ATT'Y DISCIPLINARY BOARD 34.13(5) (2005). 
past and complainants' desire to tell their stories. ${ }^{125}$ Failure to provide complainants with information on diversion can heighten their frustration and disappointment first with their treatment by their lawyers, and then their treatment in the disciplinary system. ${ }^{126}$ To avoid this risk, some diversion rules require that complainants be provided notice of the diversion decision and an opportunity to comment. ${ }^{127}$

States that do not have diversion programs should seriously consider adopting rules that allow for diversion for practice management concerns. New rules and programs can be designed to address the criticism of aspects of current approaches. For example, the disciplinary procedure rules can provide for more communication with complainants so that they better appreciate the value of diversion in preventing future misconduct. ${ }^{128}$ More communication on the alternatives to discipline can also help shape perspectives so that lawyers better understand the educational role of disciplinary authorities. ${ }^{129}$

For new diversion programs, as well as existing ones, audits or selfassessments can play an important role in helping lawyers systematically evaluate how they can improve and manage their law practices. As indicated by the research on the new regulatory regime in Australia, there was a significant reduction in complaints for firms that completed the SAP. ${ }^{130}$ My own research revealed that the majority of respondents took

125. Jennifer Gerarda Brown \& Liana G.T. Wolf, The Paradox and Promise of Restorative Attorney Discipline, 12 NEV. L.J. 253, 271 (2012) (pointing out that the diversion process leaves out the complainant and other stakeholders).

126. See id. (stating that because the specific dispute that led to the complaint might never be resolved, diversion is likely to increase "public dissatisfaction with the legal profession").

127. For example, the Wyoming Rule states:

The complainant, if any, shall be notified of the proposed decision to refer the respondent to diversion. The complainant shall have fifteen (15) days from the date of notice to submit to Bar Counsel a written comment thereon. The complainant also shall be notified when a complaint or formal charge is diverted. Decisions to divert are not appealable.

DisCIPLINARY CODE WYO. ST. B. (14)(c) (2012), available at, http://www.courts.state.wy.us/ CourtRules_Entities.aspx?RulesPage=DisciplinaryCode.xml.

128. See Norman E. Veasey, Transcript from Professionalism Conference, 54 S.C. L. REV. 897, 930 (2003) (suggesting that alternatives to discipline should be communicated more among state bar members).

129. See id. (urging more publicity of the alternatives to discipline in which the bar and disciplinary authorities provide education and support).

130. See Victoria Rees, Transforming Regulation and Governance in the Public Interest, NOVA SCOTIA BARRISTERS' SOC'Y (Oct. 15, 2013), available at http://nsbs.org/sites/default/files/ cms/news/2013-10-30transformingregulation.pdf (discussing Australia's approach to reducing complaints brought against attorneys). 
steps to revise their policies, procedures, and systems following selfassessment and close to fifty percent adopted new policies, procedures, and systems. ${ }^{131}$ These results should help directors of diversion programs recognize the value of conducting ethics audits and developing selfassessment tools.

Diversion programs enable lawyers to keep their records clean by taking steps to evaluate and improve their practice management. For those lawyers, disciplinary complaints serve as a wake-up call, motivating them to examine how they practice and handle client business. ${ }^{132}$ Lawyers who are not facing grievances should be able to obtain guidance and resources from personnel with diversion and law practice management programs. ${ }^{133}$ In an effort to be proactive in educating lawyers and avoiding complaints, bar associations should devote more resources to offices and programs that assist lawyers with law practice management. Bar groups could follow the lead of the Canadian Bar Association in developing an online tool for lawyers to voluntarily examine their practices and systems. ${ }^{134}$ Rather than relying on voluntary self-assessment, progressive jurists who embrace the concept of proactive regulation might establish a NSW-style program as a complement to discipline. ${ }^{135}$

131. See Susan Saab Fortney, Am I My Partner's Keeper? Peer Review in Law Firms, 66 U. COLO. L. REV. 329, 363 (1995) (describing the self-assessment model authorized by the ALI-ABA to be used by practitioners).

132. See KAN. SUP. CT. R. 203(d)(1)(i) (2010), available at http://www.kscourts.org/rules/rulelist.asp? $\mathrm{r} 1=$ Rules+Relating+to+Discipline+of+Attorneys (portraying how a diversion rule could allow a respondent to request that a complaint be referred to diversion).

133. As explained by Professor Ted Schneyer, Law Office Management Programs generally serve two functions: (1) a reactive one of handling a matter referred by disciplinary counsel, and (2) a proactive one in "advising lawyers who voluntarily seek their assistance on matters such as" office management. Ted Schneyer, The Case for Proactive Management Based Regulation to Improve Professional Self-Regulation for U.S. Lawyers, 42 HOFSTRA L. REV. 233, 263-64 (2013).

134. CBA Ethical Practice Self-Evaluation Tool, THE CAN. BAR. ASS'N., available at http://www.cba.org/CBA/activities/pdf/ethicalselfevaluation-e.pdf (last visited Mar. 19, 2014). The online tool sets forth ten objectives under the following general categories: (1) Relationship to Clients; (2) Relationship to Students, Employees, and Others; and (3) Relationship to Regulator, Third Parties, and the Public Generally. Id. The introduction to the tool explains that the Professional Responsibility Committee prepared the "Ethical Practices Self-Evaluation Tool to assist Canadian law firms and lawyers to systematically examine the ethical infrastructure that supports their legal practices ... [ $\mathrm{t}$ ] he goal of the Self-Evaluation Tool is not to be prescriptive but rather to encourage exploration and discussion of firm practices." Id. For each objective, the tool outlines "possible questions to ask in assessing compliance with" the objective and "potential systems and practices to ensure that the objective is met." Id. In addition, the tool links available online resources that lawyers may consult for additional guidance. $I d$.

135. See Ted Schneyer, The Case for Proactive Management Based Regulation to Improve Professional Self-Regulation for U.S. Lawyers, 42 HOFSTRA L. REV. 233, 264 (2013) (suggesting that courts establish proactive NSW-style programs as a complement to reactive discipline). Professor 
Short of imposing some type of self-assessment, courts, legislators, regulators, bar leaders, and insurers should take other steps to create incentives for lawyers to devote time and resources to serious examination of their practices. The following section discusses the role of insurance carriers in encouraging lawyers to examine and improve their management controls and systems.

\section{Insurers' Role in Promoting Self-Assessment and Development of Systems}

For decades, legal malpractice insurers have played an important role in encouraging ethical conduct by lawyers. ${ }^{136}$ Some commentators have examined the impact of insurers, examining how insurers have emerged as informal regulators of lawyer conduct. ${ }^{137}$ When it comes to risk management, the insurers' influence takes different forms.

Insurers' influence on the conduct of lawyers starts with the application for insurance that lawyers must complete to obtain insurance. ${ }^{138}$ The policy application asks a number of questions, seeking information to enable the insurer to evaluate whether the insurer will assume the risk of writing a policy, and if so, the price and terms of the coverage. ${ }^{139}$ In addition to asking general information about the prospective insured, policy applications request information relating to firm practices, policies, and systems. Common questions require applicants to describe their conflict of interest and docket control systems. ${ }^{140}$ Insurance underwriters

Schneyer further claims that a NSW-style program could be expected to cut down substantially on complaints for unprofessional conduct by "encouraging and helping firms to adhere to policies, procedures, and systems designed to forestall acts and omissions that generate those complaints." Id.

136. See Anthony E. Davis, Professional Liability Insurers as Regulators of Law Practice, 65 FORDHAM L. REV. 209, 224 (1996) (suggesting that insurers have had an impact on attorney ethical conduct for years).

137. Compare id. at 216 (arguing that insurance companies seek to "discourage, i.e., to regulate, conduct which the ethics codes and the ethics committees" deem to be risky by providing "express notice to insureds that they are on their own when it comes to liability for claims arising from such relationships"), with Charles Silver, Professional Liability Insurance As Insurance and As Lawyer Regulation: Response to Davis, 65 FORDHAM L. REV. 233, 234 (1996) ("I find Davis's proposed explanation unpersuasive. Insurers do not usually cite a desire to discourage risky conduct when justifying exclusions. They argue for exclusions on straightforward grounds having to do with their own interests.").

138. Fritz K. Huszagh, Applying for Legal Malpractice Insurance, in LEGAL MALPRACTICE: LAW OfFice GUide To PURCHASING LEgAL MALPRACTICE INSURANCE, $₫$ 6:2 (Ronald E. Mallen ed., 2012).

139. See id. (explaining that insurers use the information disclosed on the application to evaluate risk exposure based on underwriting guidelines, rules, and practices).

140. See id. $\$ 6: 2, \$ 6: 14$ (suggesting that most insurance applications require information regarding how a firm controls its calendar system and screens for conflicts or interests). 
seek this information because they recognize that the "better the procedures, the more acceptable the risk." 141 These application questions require that lawyers examine their firms' management systems and describe them on policy applications. ${ }^{142}$

As a condition of obtaining insurance or a lower premium, an insurer may require that applicant-firms complete an audit or practice review. Such a review will help the firm determine issues to be addressed and inform the insurer's underwriting decisions. ${ }^{143}$

Once insured, carriers assist insured firms with risk management. ${ }^{144}$ For example, the Attorneys' Liability Assurance Society (Bermuda) Ltd. (ALAS Ltd.), a mutual insurance company owned entirely by its insured member firms, claims to have the most comprehensive loss-prevention program for lawyers. ${ }^{145}$ Through the program, member firms can obtain educational material and a range of services, including consultations with loss prevention counsel. ${ }^{146}$

Depending on the circumstances, an insurer may provide a premium discount for particular conduct that the insurer wants to encourage. For example, an insurer may provide a premium credit for lawyers completing particular training or continuing legal education programs. ${ }^{147}$ Using a similar approach to promoting conduct that educates lawyers and lowers liability risk, insurers should provide a premium discount for lawyers who systematically examine their firm policies, procedures, and systems. As indicated by the first Australian study, a self-examination process can help address issues that lead to complaints. ${ }^{148}$ My own study revealed that the

141. See id. $\$ 6: 14$ ("Today, a law firm without a conflict of interest screening system and a calendaring system is not likely to be an acceptable risk.").

142. See id. ("Most applications request information regarding the 'housekeeping' maintained by the applicant.").

143. If a firm's insurance needs are complex or unique, Jody A. Harris, Senior Vice President and Managing Director of Gallagher Lawyer Professional Risk Services, recommends that the applicant meet with the underwriting agency. She suggests that during the meeting, the attorney emphasize the proactive steps the firm takes to avoid claims. Jody A. Harris, Purchasing Lawyers Professional Liability Insurance through an Independent Broker Specialist, in LEGAL MALPRACTICE: LaW OfFice Guide To Purchasing Legal Malpractice Insurance, $\$ 4$, $\$ 4: 7$ (Ronald E. Mallen ed., 2012). offer).

144. See id. $\$ 7: 3$ (referring to great variance between insurers and the free services that they

145. Loss Prevention, ATT'YS LIABILITY ASSURANCE SOC’Y, INC., http://www.alas.com/public/ about_lp.aspx (last visited Mar. 19, 2014).

146. Id.

147. See id. (noting that insurers often provide special workshops and seminars regarding loss prevention).

148. See Susan Fortney \& Tahlia Gordon, Adopting Law Firm Management Systems to Survive 
self-assessment process contributed to $71 \%$ of firms revising their systems, policies, and controls and $47 \%$ adopting new systems, policies, and procedures. ${ }^{149}$ A large percentage (42\%) indicated that they strengthened firm management following the SAP. ${ }^{150}$ These study results should persuade insurers to take steps to encourage lawyers to examine their firms' policies, practices, and systems as the first step in fortifying the firms' ethical infrastructure. As noted by a veteran loss-prevention expert, insurers already understand data. ${ }^{151}$ Therefore, insurers should take note of research findings related to the value of self-assessments. These studies provide support for insurers providing premium discounts for lawyers who systematically examine firm policies, procedures, controls, and systems.

To assist firms in examining their practices, insurers could also develop SAFs designed for firms of varying sizes. ${ }^{152}$ An online self-assessment tool could then link other materials, such as forms, articles, and guidelines that could assist lawyers in developing and revising their own policies, procedures, and guidance. ${ }^{153}$ Developing an effective self-assessment tool with supporting material involves a great investment of time and resources. ${ }^{154}$ Some insurers, such as companies that are members of the National Bar Related Insurance Companies, could join forces and

and Thrive: A Study of the Australian Approach to Management-Based Regulation, 10 ST. THOMAS L.J. 152, 160-62 (2012) (determining the best way to implement a self-examination process).

149. See SusAn Fortney, InCORPORATED LEgal Practice SurVey, RESUlts, at Question 12 (2012) (on file with the St. Mary's Law Journal) (showing that $42 \%$ of firms "[s]trengthened firm management [upon] completion of the Self Assessment Process").

150. Id.

151. Interview with Robert Creamer, former loss prevention counsel with ALAS, in Charleston, S.C. (Nov. 14, 2013) (expressing the view that insurers regularly make decisions based on data).

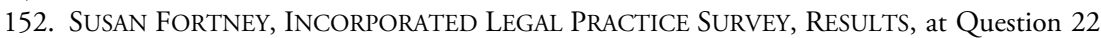
(2012) (on file with the St. Mary's Law Journal) (revealing that many respondents from small firms believed that the self-assessment instrument should be revised for more applicability to small and solo practices).

153. See CBA Ethical Practice Self-Evaluation Tool, THE CAN. BAR ASS'N., available at http://www.cba.org/CBA/activities/pdf/ethicalselfevaluation-e.pdf (last visited Mar. 19, 2014) (providing an example of an online assessment tool with links to resources); see also TLIE Self-Audit Conflict of Interest Checklist, TEX. LAW. INS. EXCH., available at http://tlie.org/prevention/self-auditconflicts.php (last visited Mar. 19, 2014) (providing a printed self-audit booklet of which portions are published online).

154. See generally ANTHONy E. DAVIS \& PeTER R. JARVIS, RisK MANAGEMENT: SuRVIVAL TOOLS FOR LAW FIRMS (2d ed. 2007) (providing an example of two legal malpractice experts who have devoted countless hours to developing checklists included in a risk management book for lawyers). 
collaborate on developing both self-assessment tools and related educational material. ${ }^{155}$

Insurers who currently provide audit services or self-assessment tools may have encountered some resistance from lawyers who expressed concern about the discovery of the results. ${ }^{156}$ To address this concern, interested parties should support the recognition of a self-evaluation privilege, discussed in the next section.

\section{The Role of Privileges}

Results from my empirical study on law firm peer review reflected the concern that lawyers may be reluctant to engage in an SAP if they believe that the information developed in the process could later be discoverable and used against them in a legal malpractice case. ${ }^{157}$ The survey instrument asked respondents to register their opinions relating to willingness to conduct peer review and perspectives on risks associated with third parties obtaining peer review results. ${ }^{158}$ In the survey of managing partners of Texas firms with ten or more lawyers, "7\% [of the respondents indicated that their firms did] not engage in formal peer review because the results might be discoverable." 159 "[Thirty-six percent of the respondents reported that] their firms would be more likely to institute peer review measures if peer review communications were protected from discovery." ${ }^{160}$ A large percentage of respondents (86\%) concurred that "peer review should be afforded confidentiality so that third parties cannot discover the results of peer review." 161 Analyzed together, these results suggest that the risk of discoverability may deter some lawyers and their

155. See THE NAT'L ASS'N OF BAR Related INS. COMPANIES, http://www.nabrico.org (last visited Mar. 19, 2014) (listing contact information and website links to member firms).

156. Susan Saab Fortney, Are Law Firm Partners Islands Unto Themselves? An Empirical Study of Law Firm Peer Review and Culture, 10 GeO. J. LEGAL ETHICS 271, 297 (1996).

157. See Susan Fortney, InCORPorated Legal Practice Survey, Results, at Question 12 (2012) (on file with the St. Mary's Law Journal) (indicating that approximately $84 \%$ of respondents claimed to review their policies and procedures after completing the SAP); see also Susan Saab Fortney, Are Law Firm Partners Islands Unto Themselves? An Empirical Study on Law Firm Peer Review and Culture, 10 GEO. J. LEGAL ETHICS 271, 296-97 (1996) (explaining the results of the empirical study related to law firm peer review).

158. See Susan Saab Fortney, Are Law Firm Partners Islands Unto Themselves? An Empirical Study on Law Firm Peer Review and Culture, 10 GEO. J. LEGAL ETHICS 271, 274 (1996) (explaining the various benefits of peer review).

159. Id. at 297.

160. Id.

161. Id. 
firms from conducting formal self-assessments, especially ones with documentation.

To provide protection for material and information developed in a practice review, firms or their insurers may retain the services of an outside lawyer to audit the practice and provide an opinion letter on findings and possible steps to improve their policies, procedures, and systems. ${ }^{162}$ Assuming that the opinion letter and related reports qualify as communications to facilitate the rendition of legal services, the firm could assert that the attorney-client privilege shields communications between the outside attorney and the client- the law firm.

A firm might use a different tack, relying on the firm's in-house general counsel or ethics advisor to conduct the self-assessment. The ability of a firm to successfully rely on attorney-client privilege to protect any report or material developed by the in-house counsel turns on various factors, including whether the self-assessment would be treated as an internal investigation that created a conflict between the interests of the firm and current client. ${ }^{163}$ For many years, courts rejected firms' claims that the attorney-client privilege protected such in-firm communications. ${ }^{164}$ Although recent court opinions have been more willing to extend protection to in-firm communications, the law is in flux. ${ }^{165}$ Even if courts extend protection to internal investigations conducted by in-house counsel (to facilitate the rendition of legal services), courts could reject a

162. See Ronald E. Mallen \& Jeffrey M. Smith, Legal Malpractice $\$ 2.5$ (2013 ed.) (noting that "the use of outside counsel can provide protection of the attorney-client privilege, which may not be available [if] inside counsel" at the firm handles risk management matters).

163. See Susan Saab Fortney, Are Law Firm Partners Islands Unto Themselves? An Empirical Study on Law Firm Peer Review and Culture, 10 GeO. J. Legal ETHICS 271, 297-300 (1996) (discussing the factors that early court opinions focused on when deciding whether an application of privilege created a conflict with current firm clients).

164. See, e.g., Elizabeth Chambliss, The Scope of In-Firm Privilege, 80 NOTRE DAME L. REV. 1721, 1725-27 (2005) (critiquing the early opinions and proposal for recognizing a privilege); see also St. Simons Waterfront, LLC v. Hunter, Maclean, Exley \& Dunn, PC, 746 S.E.2d 98, 108-09 (Ga. 2013) (adopting a fact-specific rule when determining whether in-firm counsel privilege exists if the firm takes certain steps derived from Professor Chambliss's article); Susan Saab Fortney, Are Law Firm Partners Islands Unto Themselves? An Empirical Study on Law Firm Peer Review and Culture, 10 GEO. J. LEGAL ETHICS 271, 297-300 (1996) (tracing the early developments related to in-firm privilege); ABA Formally Backs Attorney-Client Privilege for Consults with Law Firms' Inside Counsel, BLOOMBERG BNA (Aug. 28, 2013), available at http://www.bna.com/aba-formally-backs$\mathrm{n} 17179876446 /$ (providing the revised text of the August 12, 2013 ABA House of Delegates adopted resolution, which urged the legislature and the courts to recognize the privilege for communications between lawyers and in-firm counsel).

165. Anthony E. Davis, ATtorney-Client Privilege Within Firms AND LAW DEPARTMENTS, N.Y. L.J., 2 (2013) (examining "cases that have significantly expanded the ability of" firms to rely on a privilege between firm lawyers and the designated firm general counsel). 
claim that the attorney-client privilege extends to routine self-examinations or audits of firm practices, procedures, and systems.

Rather than relying on attorney-client privilege, a firm might claim that a self-critical analysis privilege shields information developed in a firm audit or SAP. A few U.S. courts have "recognized a privilege from discovery in litigation for some information produced as a result of an organization's own internal evaluation of its operation." 166 The policy justification for extending protection to information developed in internal investigations is to encourage firms to critically examine their practices, without fear that negative information would later be used against them in litigation. ${ }^{167}$ Courts have applied the privilege in different contexts, including cases involving medical peer review, securities violations, train cases, and some employment discrimination cases. ${ }^{168}$ Opinions that have applied the self-evaluation privilege have identified the following prerequisites:

1. The critical self-analysis must have been undertaken by the parties seeking protection;

2. The public must possess a strong interest in preserving the free flow of the type of information sought;

3. The information must be of the type that its free flow would be curtailed if discovery were allowed; and

4. Any document produced must have been prepared with the expectation of confidentiality and the confidentiality must, in fact, have been maintained. ${ }^{169}$

166. Stephen P. Pepe et al., Audit: Assessing Current Policies and Procedures Under Applicable Laws and Regulations, in Corp. COMPlianCe SERIES: Designing AN EFFECTIVE FAir Hiring and Termination Program 3:14 (2010-2011 ed. 2010) (citing Bredice v. Doctors Hosp., Inc., 50 F.R.D. 249, 14 Fed. R. Serv. 2d 759 (D. D.C. 1970), affd, 479 F.2d 920 (D.C. Cir. 1973)). Bredice was the first case in which the court applied a qualified privilege to protect a medical staff committee's internal communications. See Susan Saab Fortney, Are Law Firm Partners Islands Unto Themselves? An Empirical Study on Law Firm Peer Review and Culture, 10 GeO. J. LEGAL ETHICS 271, 301-02 (1996) (commenting on the Brendice opinion).

167. Stephen P. Pepe et al., Audit: Assessing Current Policies and Procedures Under Applicable Laws and Regulations, in CORP. COMPLianCe SERIES: Designing AN EFFECTIVE FAIR HiRING AND Termination Program 3:14 (2010-2011 ed. 2010) (suggesting that candid, self-critical evaluation improves organizations' compliance with legal requirements).

168. 9A William Meade Fletcher eT AL., Fletcher Cyclopedia of THE LAW OF CORPORATIONS $₫ 4670.15$ (perm. ed., rev. vol. 2008).

169. See Susan Saab Fortney, Are Law Firm Partners Islands Unto Themselves? An Empirical Study on Law Firm Peer Review and Culture, 10 GEO. J. LEGAL ETHICS 271, 301-02 (1996) (explaining the origin of all four factors); see also Dowling v. Am. Haw. Cruises Inc., 971 F.2d 423, 426 (9th Cir. 1992) (articulating the fourth factor); Note, The Privilege of Self-Critical Analysis, 96 HARV. L. REV. 1083, 1086 (1983) (identifying the first three factors). 
A firm that conducts an internal review should be able to satisfy each of these prerequisites. First, the firm conducts the self-assessment or audit to systematically evaluate and improve practices within the organization. ${ }^{170}$ Second, the public possesses a strong interest in encouraging parties to undertake critical evaluations that promise to improve the delivery of legal services and ethical conduct within law firms. ${ }^{171}$ Third, it is likely that the possibility of discovery of unfavorable information would curtail riskaverse lawyers from critically examining firm practices, procedures, and policies. ${ }^{172}$ Fourth, lawyers who conduct the examination should be prepared to demonstrate that they did so with the expectation of confidentiality and that they maintained the confidentiality. ${ }^{173}$

Lawyers may be able to improve the likelihood of a court recognizing the self-critical analysis privilege by taking the following steps:

(1) maintaining the confidentiality of the audit process;

(2) writing the audit report in a general and evaluative manner; and

(3) minimizing specific factual data in the report. ${ }^{174}$

Although these actions might put a firm in a better position to assert the self-critical analysis privilege, there is no guarantee that a court will shield information developed in the self-examination. Therefore, lawyers and their firms should approach the process recognizing that there is a risk of discoverability.

To eliminate the uncertainty related to the discoverability of selfevaluation information, lawyers could follow the lead of the medical

170. See Note, The Privilege of Self-Critical Analysis, 96 HARV. L. REV. 1083, 1086 (1983) (discussing the first factor); see also Susan Saab Fortney, Are Law Firm Partners Islands Unto Themselves? An Empirical Study on Law Firm Peer Review and Culture, 10 GeO. J. LEGAL ETHICS 271, 302 (1996) (explaining how the first factor works in tandem with the other three factors).

171. See Note, The Privilege of Self-Critical Analysis, 96 HARV. L. REV. 1083, 1086 (1983) (illustrating the second factor); see also Susan Saab Fortney, Are Law Firm Partners Islands Unto Themselves? An Empirical Study on Law Firm Peer Review and Culture, 10 GeO. J. LEGAL ETHICS 271, 302-03 (1996) (detailing the impact the second factor has on the entire analysis).

172. See Note, The Privilege of Self-Critical Analysis, 96 HARV. L. REV. 1083, 1086 (1983) (stating the third factor); see also Susan Saab Fortney, Are Law Firm Partners Islands Unto Themselves? An Empirical Study on Law Firm Peer Review and Culture, 10 GeO. J. Legal ETHICS 271, 303 (1996) (commenting on the impact the third factor has on the decision process).

173. See Dowling, 971 F. 2d at 426 (discussing the importance of the expectation of privacy). To satisfy the last prerequisite, the firm should not share the results of the self-assessment with third persons, such as insurers, if doing so would jeopardize the protection of the self-critical assessment privilege.

174. Stephen P. Pepe et al., Audit: Assessing Current Policies and Procedures Under Applicable Laws and Regulations, in CORP. COMPLianCe SERIES: Designing AN EFFECTIVE Fair HiRing AND TERMINATION PROGRAM 3:14 (2010-2011 ed. 2010). 
profession and seek statutory protection, similar to that afforded to medical peer-review communications. All states now recognize a medical peer-review privilege to varying degrees. ${ }^{175}$ "Peer review is the process by which healthcare providers evaluate and assess deficiencies in the quality of physician services provided in the healthcare setting." 176 Peer-review information is protected to encourage healthcare providers to critically and candidly evaluate deficiencies in the quality of medical services, without the concern that information could later be used "in a medical malpractice case." 177 Although some might question whether the peer-review privilege fosters a "conspiracy of silence" among doctors, physicians maintain that protection is necessary to maximize the quality of care that patients receive. ${ }^{178}$

Similarly, a statutory self-evaluation privilege for lawyers could serve the public interest by creating a comfort zone so that lawyers can critically examine and improve their practices without the fear of discovery. Recognizing the value of such a project, a group of risk management experts proposed a privilege for risk audits of law firms. ${ }^{179}$ "[The] proposal was created by a now defunct organization, The Lawyer Risk Management Association."180 "The principal drafters were Margaret Hepper and James C. Belding, now at Aon Affinity Insurance Services ... . and Anthony E. Davis, now a partner in the Lawyers for the Profession ${ }^{\oplus}$

175. See Ann B. Clairbone et al., Legal Impediments to Implementing Value-Based Purchasing in Healthcare, 35 AM. J. L. \& MED. 442, 470 (2009) (examining the impact peer review has had on the medical field); see also J. Matthew Anderson, The Medical Peer Review Privilege: Illustrative Cases of the Public Policy Supporting the Privilege and a Practical Approach to Presenting the Case for Protection, 46 TORT TRIAL \& INS. PRAC. L.J. 95, 97-99 (2010) (discussing the scope and application of the privilege).

176. Ann B. Clairbone et al., Legal Impediments to Implementing Value-Based Purchasing in Healthcare, 35 AM. J. L. \& MED. 442, 470 (2009).

177. See id. ("It serves to assure physicians that the peer review committee's analysis of physician performance will not be used against such physicians in a medical malpractice case.”).

178. Compare B. Abbott Goldberg, The Peer Review Privilege: A Law in Search of a Valid Policy, 10 AM. J.L. \& MED. 151, 160-61 (1984) (warning that the privilege has evolved into a vehicle that enables hospitals to conceal the evidence of their own neglect), with F. Dean Griffen, The Challenge to Confidentiality in Peer Review, Am. Coll. Of Surgeons, Division of Advoc. AND Health POLICY, available at http://www.facs.org/ahp/proliab/0599a.html (last revised Oct. 28, 2011) (referring to peer review as "an important tool used to evaluate and maximize the quality of care that patients receive").

179. See Email from Anthony C. Davis to Susan Fortney (Nov. 8, 2013, 10:15 A.M.) (on file with the St. Mary's Law Journal) (stating that the proposed privilege for risk audits was drafted in 1997 by a now disbanded organization).

180. Id.; Email from James C. Belding to Anthony C. Davis, (Nov. 8, 2013, 10:21 A.M.) (on file with the St. Mary's Law Journal). 
practice group of Hinshaw \& Culbertson LLP." 181 As stated in the proposal's Preamble, communications relating to "voluntary internal risk management audits" are "privilege[d] from discovery or use as evidence in any civil proceedings" so that lawyers are encouraged "to undergo voluntary internal risk management audits of their management policies." 182 After defining terms, the proposal sets forth the privilege as follows: "Any privileged information prepared in connection with or which directly relates to a risk management audit conducted in accordance with [the definitions] is not subject to discovery or admissible in evidence in any civil proceeding." 183 This proposal can serve as a model when advocating for an expanded self-critical analysis privilege to cover information developed in law firm audits and self-assessments. ${ }^{184}$

181. Email from Anthony C. Davis to Susan Fortney, (Nov. 8, 2013, 10:15 A.M.) (on file with the St. Mary's Law Journal); Email from James C. Belding to Anthony C. Davis, (Nov. 8, 2013, 10:21 A.M.) (on file with the St. Mary's Law Journal).

182. Risk Management Audits for Lawyers and Law Firms; Privilege From Discovery and Use in Civil Proceedings, THE LaWyer Risk Management Association, Draft (1997) (on file with the St. Mary's Law Journal) ("This privilege does not exist with respect to lawyer discipline proceedings.").

183. See id. at Section 2 (clarifying that the privilege does not extend to firms' records "not prepared as part of or in connection with the risk management audit”).

184. The following is the text of the proposed privilege:

Section 1. Definitions:

(a) "Risk management audit" means a voluntary, internal assessment, evaluation or review that is performed by a lawyer or by a partner or shareholder of a law firm, an employee of the lawyer or law firm, or by a third party person or entity who conducts such audit or assists the law firm in the implementation of any finding or recommendation made in connection with such audit, and initiated by the principal, a partner or shareholder of the law firm for the purpose (i) of determining whether the systems, policies and procedures for the management of the law firm are adequate or appropriate to the needs of the law firm and meet requirements of professional responsibility or (ii) of implementing any finding or recommendation made in connection with such audit.

(b) "Risk management audit report" means any report, whether written or oral, prepared or communicated as a result of or in response to a risk management audit. A risk management audit report may include the following supporting information, if prepared or developed for the primary purpose and in the course of an audit: notes and records of observations, findings, opinions, suggestions, conclusions, drafts, memoranda, computergenerated or electronically recorded information, and surveys.

(c) "Privileged information" means a risk management audit report and any information, opinion, communication, report or record, whether written or oral, to which the evidentiary privilege attaches pursuant to Section 2 (a) of this Act.

(d) "Civil proceeding" and "civil action" mean any civil litigation, including but not limited to any alternative dispute resolution procedure. "Civil proceeding" and "civil action" does not mean lawyer professional discipline proceedings, with respect to which the privilege established by Section 2 (a) of this Act shall not apply. 


\section{CONCLUSION: BUILDING PARTNERSHIPS AMONG PRACTITIONERS, REGULATORS AND INSURERS}

Regulators, bar leaders, and legal ethics experts around the world are monitoring the Australian experience with management-based regulation of lawyers. The Australian statute allowing non-lawyer ownership of law firms effectively pushed incorporated firms to develop their ethical infrastructures. First, the law requires that the firms appoint a legal practitioner director to be responsible for ethical conduct within the organization. Second, it requires that incorporated firms implement and

Section 2. Privilege In Civil Proceedings

(a) Any privileged information prepared in connection with or which directly relates to a risk management audit conducted in accordance with Section 1 of this Act is not subject to discovery or admissible in evidence in any civil proceeding. Information, documents or other records otherwise existing and available as part of the records of the law firm and not prepared as part of or in connection with a risk management audit are not privileged in a civil proceeding merely because such information, documents or records were presented or considered in connection with a risk management audit.

(b) No person shall be required to disclose by way of testimony or otherwise or to produce under subpoena or otherwise any protected information, and no such privileged information may be used in connection with any civil action or proceeding, or in any discovery procedure in any civil action or proceeding.

Section 3. Exception: Waiver

(a) The privilege established by Section 2 of this Act does not apply to the extent the privilege is expressly waived by any person with authority to do so on behalf of the law firm that ordered the risk management audit report or caused the risk management audit to be conducted.

(b) Disclosure of any privileged information does not waive the privilege established by Section 2 of this Act if the disclosure is made:

(i) to a person to whom the audit results are disclosed and who is either the principal, a partner, shareholder or the employee of a law firm in connection with whose professional practice the risk management audit was conducted;

(ii) to a legal representative of a person included within paragraph (1) hereinabove;

(iii) to an employee of a person or entity that receives any privileged information, in the ordinary course of business and who or which is engaged in the business of obtaining or placing professional liability insurance coverage or which is engaged in the business of insuring, underwriting, or indemnifying attorneys; or

(iv) subject to the terms of a confidentiality agreement between the lawyer or the law firm which ordered the risk management audit or caused the risk management audit to be conducted and a third party where such disclosure is made to such third party for the purpose of obtaining advice or assistance from such third party in the implementation of any finding or recommendation made in connection with a risk management audit report.

Id. at Section 1 to Section 3. 
maintain AMS. Because the statute does not define the systems or manner for determining compliance, the regulator worked with interested parties, including practitioners and legal malpractice insurers, to develop a regulatory regime. In collaboration, stakeholders developed ten objectives of good practice as well as an SAP for incorporated firms to evaluate and rate their compliance with the objectives. This process enables lawyers to systematically learn about management controls and obtain guidance from the regulators.

Early studies evaluating the "education toward compliance" approach revealed a relationship between firms' completion of the self-assessment process and a significant reduction of the number of complaints filed against lawyers in the firm. To obtain more data on the effects of the selfassessment process, I conducted a two-phase study. As discussed above, the study revealed that the self-assessment process contributed to development of management systems within firms. The greatest reported impact was on firm management and risk management. Taken together, results from these studies make a compelling case for implementing proactive approaches to regulation.

Implementation of management-based principles can help transform a lawyer disciplinary system from a reactive one to a proactive one that educates and assists lawyers in conducting their practices ethically and efficiently. To start the process of integrating management-based approaches, regulators and insurers can encourage self-assessment and educational initiatives to assist lawyers in improving their management practices, avoiding complaints, and lowering malpractice exposure. They should create programs and incentives for lawyers to examine their firms' practices and controls. At the same time, they should seek to address disincentives, such as the risk of discoverability from results of the selfexamination or audit.

The steps outlined in Part III of this Article can help regulators and insurers reshape their relationships with lawyers and the public. Through educational programs, insurers and regulators work with lawyers-not against them. They effectively partner with lawyers in assisting them to develop management systems and practice controls. This approach promises to protect the public more than the current disciplinary system in which aggrieved persons obtain limited assistance and redress. Rather than relying on a reactive system that processes complaints after misconduct occurs, clients and the public will fare much better if regulators and insurers work with firm and bar leaders to create programs that help lawyers improve their practices by avoiding problems before they happen. 
